\title{
Genetic Variation of hTERT, Leukocyte Telomere Length and the Risk of Breast Cancer: A Case-Control Study in Egyptian Females
}

\author{
Shaymaa E. El Feky'1, Fawziya A. Ibrahim², Medhat Haroun'3 , Mohammad Abdel-Rahman \\ Ahmmad4, Mostafa Elnaggar5, Safaa Elghandour ${ }^{3}$, Nadia A. Abd El Moneim5 \\ ${ }^{1}$ Department of Radiation Sciences, Medical Research Institute, University of Alexandria, Alexandria, Egypt \\ ${ }^{2}$ Department of Applied Medical Chemistry, Medical Research Institute, University of Alexandria, Alexandria, Egypt \\ ${ }^{3}$ Department of Biotechnology, Institute of Graduate Studies and Research, University of Alexandria, Alexandria, Egypt \\ ${ }^{4}$ Military Medical Academy, Alexandria, Egypt \\ ${ }^{5}$ Department of Cancer Management and Research, Medical Research Institute, University of Alexandria, Alexandria, Egypt \\ Email: shaymaa.elfeky@alexu.edu.eg
}

How to cite this paper: El Feky, S.E., Ibrahim, F.A., Haroun, M., Ahmmad, M.A.-R., Elnaggar, M., Elghandour, S. and El Moneim, N.A.A. (2019) Genetic Variation of hTERT, Leukocyte Telomere Length and the Risk of Breast Cancer: A Case-Control Study in Egyptian Females. Advances in Breast Cancer Research, 8, 61-76.

https://doi.org/10.4236/abcr.2019.82005

Received: March 13, 2019

Accepted: April 27, 2019

Published: April 30, 2019

Copyright (c) 2019 by author(s) and Scientific Research Publishing Inc. This work is licensed under the Creative Commons Attribution International License (CC BY 4.0).

http://creativecommons.org/licenses/by/4.0/

\begin{abstract}
Background: $h T E R T$ is a key player in telomere biology and its activity is directly related to cell senescence and development of many health-related problems including cancer. Although previous studies investigated this association, the results greatly vary among populations. This study aimed to investigate the association of $h T E R T$ gene SNPs and the risk of breast cancer (BC) in Egyptian females and their impact on telomere length (TL). Methods: $218 \mathrm{BC}$ patients and 178 age-matched healthy females were genotyped for $h T E R T$ variants rs2736098G > A, rs2735940C > T using PCR-RFLP and for MNS16A tandem repeat using PCR to determine their association with breast cancer risk. Telomere length was measured using $q P C R$. Results: hTERT rs2736098G > A results indicated that both AG and GG genotypes and $\mathrm{G}$ allele were associated with an increased risk of BC. The rs2735940 TT genotype was significantly associated with BC risk, however, the MNS16A tandem repeat region polymorphism didn't show any correlation with the risk of developing BC. TL showed a significant reduction in BC patients with age $<40$ years compared with controls. However, it didn't show a significant difference above the age of 40 years. Conclusions: hTERT rs2736098 and rs27365940, not MNS16A may be associated with an increased risk of developing BC in Egyptian females. Also, telomere length can be a promising screening marker of $\mathrm{BC}$ especially in young population.
\end{abstract}

\section{Keywords}

Human Telomerase Reverse Transcriptase (hTERT), Single Nucleotide 
Polymorphism, Telomere Length, Breast Cancer Risk

\section{Introduction}

Breast cancer (BC) is a serious health problem that women face around the world. In 154 of 185 countries, BC is the most frequently diagnosed cancer according to the GLOBOCAN 2018 and is the highest mortality cause in women in more than 100 countries [1]. The most rapid increase in incidence rates of BC shows an incline in countries that have been historically relatively low like South America, Africa, and Asia [2]. BC pathogenesis is affected by several factors, including genetic, family history, lifestyle, endocrine factors, as well as social and economic development [3]. However, there is a compelling need to clarify its exact etiology.

Telomeres are (TTAGGG)n repetitive sequences of DNA that can be found at the ends of chromosomes. Telomeres function is to maintain genetic stability by protecting chromosome during repetitive DNA replication cycles [4]. Due to the end-replication problem, telomeres are shortened in most somatic tissues, and are proposed physiological markers of aging and age-related pathology as well as cancer [5]. The function of telomeres and its role in cancer development is mainly determined by telomere length (TL) [6]. Although shortened telomeres can induce apoptosis, a critical length threshold is required. Otherwise, cells may bypass such signals and lead to what is known as telomere crisis. During telomere crisis, genomes experience an extensively unstable state that is a typical event in cancer progression [7] [8].

Telomeres are maintained by the telomerase complex, which consists of the Telomerase reverse transcriptase (TERT) catalytic subunit encoded by gene positioned at chromosome 5p15.33, and the Telomerase RNA component (TERC) encoded by the gene positioned on chromosomal region $3 \mathrm{q} 26$, with several other associated proteins required for proper telomerase assembly and recruitment to chromosomes [9]. While TERC is widely expressed, hTERT is downregulated in most human somatic cells leading to progressive telomere shortening [10].

Given the key role of $h T E R T$ in maintaining telomere stability, several common functional single nucleotide polymorphisms (SNPs) of the hTERT gene promoter region may impact the risk of different types of cancers [11] [12]. The relationship between $h T E R T$ polymorphisms and BC risk has been investigated in a number of studies [13] [14] [15]. Downstream of the $h T E R T$ gene, a polymorphic region known as the MNS16A minisatellite region was also found to be linked with the $h T E R T$ activity in many types of cancers [16] [17], however, the results were inconclusive.

The association of $h T E R T$ genomic variation with tumor biology draws attention to the need to verify this relation in different populations with diverse ancestries. In this case-control study, we genotyped a number of $h T E R T$ variants 
(rs2736098G > A, rs2735940C > T and MNS16A) since the previous studies reached paradoxical conclusions regarding their association with cancer risk. We also measured the leukocyte telomere length and analyzed their association with $\mathrm{BC}$ risk in a sample of Egyptian females.

\section{Methods}

\subsection{Patients}

This case-control study enrolled 218 Egyptian breast cancer female patients who were referred to the Medical Research Institute and Ayadi Al-Mostakbal hospitals (Egypt) and 178 age-matched healthy females; they were unrelated to the patients and had no history of any type of cancer. Ethical approvals for recruitment were obtained from the local Ethics Committee of Medical Research Institute, University of Alexandria, and informed consent was obtained from each patient and healthy individual.

\subsection{DNA Extraction}

Whole blood samples were collected from breast cancer patients and healthy controls into EDTA-coated Vacutainer tubes and stored at $-80^{\circ} \mathrm{C}$ till genomic DNA was extracted. Genomic DNA was extracted using Invitrogen PureLink ${ }^{\text {тм }}$ Genomic DNA Mini Kit (Thermo Fischer Scientific, USA) according to the manufacturer's instructions. The purity and concentration of DNA were evaluated by NanoDrop ${ }^{\circledast}$ ND-1000 UV-Visible Spectrophotometer (Thermo Fischer Scientific, USA). The extracted DNA was stored at $-20^{\circ} \mathrm{C}$ for further use.

\section{3. hTERT Genotyping}

Polymerase chain reaction-restriction fragment length polymorphism (PCR-RFLP) analysis was performed for genotyping of $h T E R T$ rs2736098G > A and rs2735940C > T polymorphisms. The primers' sequences, length of amplified DNA fragments, restriction pattern, and restriction enzymes used are presented in Table 1. PCR reactions were performed in a final volume of $25 \mu$ l contained $12.5 \mu \mathrm{l}$ of $2 \mathrm{x}$ Dream Taq green master mix with dual dye (Thermo Fischer Scientific, USA), $100 \mathrm{ng}$ genomic DNA, $0.2 \mu \mathrm{mol}$ of each appropriate primer. The PCR cycling conditions were: a denaturation step of $5 \mathrm{~min}$ at $95^{\circ} \mathrm{C}$; 30 cycles of $30 \mathrm{~s}$ at $94^{\circ} \mathrm{C}$, $30 \mathrm{~s}$ at $57^{\circ} \mathrm{C}$ (for rs $2736098 \mathrm{G}>\mathrm{A}$ ) or $56^{\circ} \mathrm{C}$ (for rs $2735940 \mathrm{C}>\mathrm{T}$ ), and $30 \mathrm{~s}$ at $72^{\circ} \mathrm{C}$; a final elongation step of $7 \mathrm{~min}$ at $72^{\circ} \mathrm{C}$. Each PCR product was digested using $10 \mathrm{U}$ of the corresponding restriction enzyme Bsp120I at $37^{\circ} \mathrm{C}$ for 1 hour then the reaction was stopped by incubation at $80^{\circ} \mathrm{C}$ for 10 minutes. After digestion, then the products were electrophoresed on $3 \%$ agarose gel containing 0.5 $\mu \mathrm{g} / \mathrm{mL}$ ethidium bromide and visualized under UV illumination.

The MNS16A variable number of tandem repeat polymorphisms was genotyped using PCR as Wang et al. [18] reported previously. The primers' sequences and length of amplified DNA fragments were also mentioned in Table 1 . The PCR conditions started with an initial denaturation step of $5 \mathrm{~min}$ at $95^{\circ} \mathrm{C} ; 30$ 
Table 1. Primer sequences, DNA fragment length and restriction enzyme and restriction pattern (if available) for $h T E R T$ rs2736098, rs2735940 and MNS16A polymorphisms.

\begin{tabular}{|c|c|c|c|c|}
\hline Polymorphism & Primer Sequence & $\begin{array}{l}\text { DNA fragment } \\
\text { Length }\end{array}$ & $\begin{array}{l}\text { Restriction } \\
\text { Enzyme }\end{array}$ & $\begin{array}{l}\text { Restriction } \\
\text { pattern (bp) }\end{array}$ \\
\hline rs2736098 $(\mathrm{G}>\mathrm{A})$ & $\begin{array}{l}\text { F: 5'AGGACGCGTGGACCGAGTGA-3' } \\
\text { R: 5'GGAACCCAGAAAGATGGTCTC-3' }\end{array}$ & $324 \mathrm{bp}$ & $\begin{array}{l}\text { Bsp120I } \\
\text { (PspOMI) }\end{array}$ & $\begin{array}{c}\text { AA: } 324, \\
\text { AG: } 324,187,137 \\
\text { GG: } 137,187\end{array}$ \\
\hline rs2735940 $(\mathrm{T}>\mathrm{C})$ & $\begin{array}{l}\text { F: 5' ATCTTCTGCTTCCATTTCTTCTC 3' } \\
\text { R: 5'TCGTCTTGTAAATACTTAGGATTCC 3' }\end{array}$ & $235 \mathrm{bp}$ & MspI (HpaII) & $\begin{array}{c}\text { TT: } 235 \\
\text { TC: } 235,211,24 \\
\text { CC: } 211,24 .\end{array}$ \\
\hline MNS16A & $\begin{array}{l}\text { F: 5'-AGGATTCTGATCTCTGAAGGGTG-3' } \\
\text { R: 5'-TCTGCCTGAGGAAGGACGTATG-3' }\end{array}$ & $\begin{array}{l}\text { S: } 243,272 \mathrm{bp} \\
\text { L: } 333,302 \mathrm{bp}\end{array}$ & -- & -- \\
\hline
\end{tabular}

cycles of $30 \mathrm{~s}$ at $94^{\circ} \mathrm{C}, 30 \mathrm{~s}$ at $57^{\circ} \mathrm{C}$, and $30 \mathrm{~s}$ at $72^{\circ} \mathrm{C}$; a final elongation step of 7 min at $72^{\circ} \mathrm{C}$. The PCR product was then electrophoresed on $3 \%$ agarose gel containing $0.5 \mu \mathrm{g} / \mathrm{mL}$ ethidium bromide and visualized under UV illumination.

\subsection{Telomer Length Determination}

Leukocyte telomere length measurement was carried out according to the quantitative PCR method reported previously by Gil et al. [19]. The rhodopsin gene was selected as single copy gene to normalize the telomere PCR. The primer sequences for both telomere length and rhodopsin were as follows: Telomere Length 1 5'-CGGTTTGTTTGGGTTTGGGTTTGGGTTTGGGTTTGGGTT-3'; Telomere Length 2 5'-GGCTTGCCTTACCCTTACCCTTACCCTTACCCTTACCCT-3' Rhodopsin Forward 5'-CGTGGCCTGGTACATCTTCA-3' and Rhodopsin Reverse 5'-ACGCCGGCAGGGTCAT-3'. All samples were run in an Applied Biosystems Real-Time PCR System (Applied Biosystems, Foster City, CA). PCR reactions were performed in a final volume of $25 \mu \mathrm{l}$ contained $12.5 \mu \mathrm{l}$ of SYBR Green master mix (Thermo Fischer Scientific, USA), 100 ng genomic DNA, 2.5 $\mu \mathrm{l}$ primers, $8 \mu \mathrm{l}$ DNase-free water. The PCR cycling conditions were a denaturation step of $10 \mathrm{~min}$ at $95^{\circ} \mathrm{C}$ followed by 25 cycles of $15 \mathrm{~s}$ at $95^{\circ} \mathrm{C}, 120 \mathrm{~s}$ at $54^{\circ} \mathrm{C}$. The Ct was calculated for both telomere and Rhodopsin were calculated. Telomere length was represented as a T/S ratio where $(\mathrm{T})$ represented the telomere repeat copy number and $(S)$ represented the single copy gene number according to the equation reported previously [20].

\subsection{Statistical Analysis}

Statistical analysis was performed using the Statistical Package for Social Sciences Software (SPSS 21; SPSS Inc.; Chicago, IL, USA). The frequencies of genotypes, alleles between breast cancer patients and healthy control as well as the clinicopathological characteristics were analyzed using Person chi-square test. The association between genotypes and alleles and the risk of breast cancer were assessed by computing the odds ratio (OR) and $95 \%$ confidence intervals 
(95\% CI) from unconditional logistic regression analyses. The statistical analysis of telomere length was performed using Mann-Whitney $\mathrm{U}$ nonparametric test. A $\mathrm{p}$ value of $<0.05$ was considered statistically significant. The Hardy-Weinberg equilibrium was tested for all polymorphisms.

\section{Results}

\subsection{Characteristics of Study Population}

The age of breast cancer patients and healthy controls enrolled in the study are presented in Table 2. There was no significant difference between patients and controls regarding age $(\mathrm{p}=0.464)$. Table 2 also presents the distribution of clinical characteristics of breast cancer patients including histological grade, axillary lymph node involvement and receptors' status.

Table 2. Description of the Clinicopathological Characteristics of Breast Cancer Patients.

\begin{tabular}{|c|c|c|}
\hline \multirow{2}{*}{$\begin{array}{c}\text { Characteristic } \\
\text { Age }\end{array}$} & \multicolumn{2}{|c|}{$\begin{array}{l}\text { Breast Cancer Patients } \\
\text { n-218 }\end{array}$} \\
\hline & Mean \pm S.D. & $49.68 \pm 1.39$ \\
\hline \multirow[t]{2}{*}{ Menstrual status } & Perimenopausal & $83(38 \%)$ \\
\hline & Postmenopausal & $135(62 \%)$ \\
\hline \multirow[t]{3}{*}{ Family History } & Positive & $47(21.6 \%)$ \\
\hline & Negative & $169(77.5 \%)$ \\
\hline & Unknown & $2(0.9 \%)$ \\
\hline \multirow[t]{2}{*}{ Tumor type } & Invasive Ductal Carcinoma & $213(97.7 \%)$ \\
\hline & Invasive Lobular Carcinoma & $5(2.3 \%)$ \\
\hline \multirow[t]{3}{*}{ Histological Grade } & II & $165(75.7 \%)$ \\
\hline & III & $51(23.4 \%)$ \\
\hline & Unknown & $2(0.9 \%)$ \\
\hline \multirow[t]{3}{*}{ Vascular Invasion } & Positive & $145(66.6 \%)$ \\
\hline & Negative & $71(32.5 \%)$ \\
\hline & Unknown & $2(0.9 \%)$ \\
\hline \multirow{3}{*}{$\begin{array}{l}\text { Axillary Lymph Node } \\
\text { Involvement }\end{array}$} & Positive & $161(73.9 \%)$ \\
\hline & Negative & $55(25.2 \%)$ \\
\hline & unknown & $2(0.9 \%)$ \\
\hline \multirow[t]{2}{*}{ Estrogen Receptor (ER) } & Positive & $146(66.7 \%)$ \\
\hline & Negative & $72(33.3 \%)$ \\
\hline \multirow[t]{2}{*}{ Progesterone Receptor (PR) } & Positive & $131(60 \%)$ \\
\hline & Negative & $87(40 \%)$ \\
\hline \multirow[t]{3}{*}{ Her2/neu Receptor } & Positive & $66(30.3 \%)$ \\
\hline & Negative & $142(65.1 \%)$ \\
\hline & Unknown & $10(4.6 \%)$ \\
\hline
\end{tabular}




\subsection{The Impact of $h T E R T$ rs2736098G $>A$, rs2735940C $>$ T and MNS16A on Breast Cancer Risk}

The different genotypes of studied hTERT polymorphisms are illustrated in Figure 1. The genotype and allele frequencies of hTERT polymorphisms for breast cancer cases and controls as well as their association with BC risk are presented in Table 3. The statistical analysis of rs2736098G $>$ A frequency distribution showed that the GG increased the risk of breast cancer (OR $=7.484,95 \% \mathrm{CI}$ $=2.593-21.597, \mathrm{p} \leq 0.001$ and $\mathrm{OR}=1.146,95 \% \mathrm{CI}=1.080-1.216, \mathrm{p} \leq 0.001$ respectively) compared to AA genotype which significantly lowered the risk of $\mathrm{BC}(\mathrm{OR}=0.332,95 \% \mathrm{CI}=0.195-0.563, \mathrm{p} \leq 0.001)$. Our results also indicated that the $\mathrm{G}$ allele was associated with higher $\mathrm{BC}$ risk compared to the A allele (OR $=1.743,95 \% \mathrm{CI}=1.168-2.600, \mathrm{p}=0.006$ ). The $\mathrm{rs} 2735940 \mathrm{C}>\mathrm{T}$ genotyping showed that the TT genotype was associated with a significant increase in the risk of $\mathrm{BC}$ compared to the rest of genotypes $(\mathrm{OR}=1.519,95 \% \mathrm{CI}=1.008$ 2.289, $\mathrm{p}=0.045)$. However, neither the MNS16A genotypes nor its alleles showed any association with $\mathrm{BC}$ risk or protection. The association between the studied $h T E R T$ polymorphisms and BC risk was further examined by stratifying the subjects according to tumor histology (Table 4).

\subsection{Telomere Length}

Subjects in both BC and control groups were stratified into two subgroups according to their age with cut-off 40 years of age. For estimating the leukocyte telomere length, the telomere/single copy gene (T/S) ratio was calculated for all subjects. The statistical analysis revealed that the T/S ratio of $\mathrm{BC}$ patients with age less than 40 years showed a significant reduction in TL compared with controls with matched age, however, the TL in both patients and controls with age older than 40 years did not show a significant difference $(\mathrm{p} \leq 0.001$ and 0.963 respectively) (Figure 2). In our study, the mean TL changed with different $h T E R T$ polymorphisms genotypes. For rs2736098G > A, the TL decreased with every $\mathrm{G}$ allele, and the T/S ratio was 1.14 for $\mathrm{AA}, 0.71$ for $\mathrm{AG}$, and 0.40 for GG, respectively. The GG genotype was significantly shorter than the AA genotype ( $\mathrm{p}$ $=0.045$ ). For the rs $2735940 \mathrm{C}>\mathrm{T}$ polymorphism, and $\mathrm{T} / \mathrm{S}$ ratio was 1.22 for $\mathrm{CC}$, 0.88 for TC, and 0.56 for TT. Both CT and TT genotypes were significantly shorter than the CC genotype ( $\mathrm{p}=0.002$ and $<0.001$ respectively). Regarding the MNS16A tandem repeat, the mean T/S ratio was 1.62 for LL, 0.83 for LS and 0.54 for SS genotypes. The LS and SS genotypes were also significantly shorter than the LL genotype ( $\mathrm{p}=0.012$ and 0.062 respectively) (Figure 3).

\section{Discussion}

Given the fact that telomeres are maintained by telomerase complex, it's been proposed that genetic polymorphisms in its catalytic subunit $h T E R T$ can have a significant influence on the predisposition to developing cancer [21]. In the current case-control study, we investigated the association of three SNPs in the 
hTERT gene with the risk of $\mathrm{BC}$ in a sample of Egyptian females. Our results indicated that the GG genotype and G allele of $h T E R T \mathrm{rs} 2736098 \mathrm{G}>\mathrm{A}$ and TT genotype of rs2735940C > T were associated with increased risk for BC, while MNS16A didn't show any significant association.

Table 3. Genotype and allele frequencies distribution of hTERT polymorphisms (rs2736098, rs2735940 and MNS16A) in breast cancer patients and healthy control groups and their association with breast cancer risk.

\begin{tabular}{|c|c|c|c|c|c|c|}
\hline & $\mathrm{BC}$ patients & Control & \multirow{2}{*}{$\mathrm{X}^{2}$} & \multirow{2}{*}{ p-value } & \multirow{2}{*}{ Odds ratio } & \multirow{2}{*}{$\begin{array}{l}95 \% \text { CI } \\
\text { LL-UL }\end{array}$} \\
\hline & $\mathrm{n}=218$ & $\mathrm{n}=178$ & & & & \\
\hline \multicolumn{7}{|c|}{ rs2736098 } \\
\hline \multicolumn{7}{|c|}{ Genotypes } \\
\hline AA & 25 (11.5\%) & $48(27.3 \%)$ & 15.456 & $<0.001$ & 1 & - \\
\hline AG & $161(73.8 \%)$ & $124(70.5 \%)$ & 0.999 & 0.318 & 1.230 & $0.792-1.909$ \\
\hline GG & $32(14.7 \%)$ & $4(2.2 \%)$ & 14.774 & $<0.001$ & 7.484 & $2.593-21.597$ \\
\hline \multicolumn{7}{|c|}{ Alleles } \\
\hline A & $(48.4 \%)$ & $(62.5 \%)$ & & & 1 & - \\
\hline G & $(51.5 \%)$ & $(37.5 \%)$ & 7.447 & 0.006 & 1.743 & $1.168-2.600$ \\
\hline \multicolumn{7}{|c|}{ rs2735940 } \\
\hline \multicolumn{7}{|c|}{ Genotypes } \\
\hline $\mathrm{CC}$ & $28(12.8 \%)$ & $30(16.9 \%)$ & 1.255 & 0.263 & 1 & - \\
\hline $\mathrm{TC}$ & $95(43.6 \%)$ & $88(49.4 \%)$ & 1.447 & 0.229 & 0.790 & $0.531-1.175$ \\
\hline $\mathrm{TT}$ & $95(43.6 \%)$ & $60(33.7 \%)$ & 4.223 & 0.040 & 1.519 & $1.008-2.289$ \\
\hline \multicolumn{7}{|c|}{ Alleles } \\
\hline $\mathrm{C}$ & $(36 \%)$ & $(40 \%)$ & & & 1 & - \\
\hline $\mathrm{T}$ & $(65 \%)$ & $(60 \%)$ & 2.567 & 0.109 & 1.41 & $0.926-2.147$ \\
\hline
\end{tabular}

MNS16A

Genotypes

$\begin{array}{llllllc}\text { LL } & 80(36.7 \%) & 55(30.9 \%) & 1.353 & 0.245 & 1 & - \\ \text { LS } & 86(39.4 \%) & 68(38.2 \%) & 0.095 & 0.758 & 1.054 & 0.702-1.582 \\ \text { SS } & 52(23.9 \%) & 55(30.9 \%) & 2.458 & 0.117 & 0.701 & 0.449-1.093\end{array}$

Alleles 
Table 4. Association of the hTERT polymorphisms (rs2736098, rs2735940 and MNS16A) genotypes with clinicopathological characteristics.

\begin{tabular}{ccccccccccc}
\hline & \multicolumn{3}{c}{$\begin{array}{c}\text { hTERT } \\
\text { Characteristics }\end{array}$} & \multicolumn{3}{c}{ rs2736098 } & \multicolumn{5}{c}{$\begin{array}{c}\text { hTERT } \\
\text { rs2735940 }\end{array}$} & \multicolumn{3}{c}{ MTERT } \\
& ANS16A \\
\hline Family History & & AG & GG & CC & TC & TT & LL & LS & SS \\
Positive & 9 & 41 & 2 & 9 & 20 & 18 & 10 & 22 & 14 \\
Negative & 16 & 118 & 30 & 19 & 75 & 75 & 69 & 63 & 38 \\
X & 2.200 & 0.966 & 6.529 & 1.693 & 0.023 & 0.555 & 5.545 & 1.759 & 1.294 \\
p-value & 0.138 & 0.326 & 0.011 & 0.193 & 0.880 & 0.463 & 0.019 & 0.185 & 0.255 \\
Grade & & & & & & & & & \\
II & 20 & 114 & 29 & 24 & 79 & 56 & 58 & 63 & 42 \\
III & 4 & 46 & 2 & 4 & 15 & 38 & 21 & 22 & 10 \\
X & 0.315 & 5.916 & 6.394 & 2.426 & 9.323 & 19.122 & 0.281 & 0.137 & 1.041 \\
p-value & 0.575 & 0.015 & 0.011 & 0.119 & 0.002 & $<0.001$ & 0.596 & 0.711 & 0.307
\end{tabular}

Axillary Lymph Nodes Involvement

$\begin{array}{cccccccccc}\text { Positive } & 19 & 125 & 17 & 18 & 79 & 63 & 70 & 58 & 40 \\ \text { Negative } & 5 & 35 & 15 & 9 & 16 & 31 & 10 & 27 & 11 \\ \mathrm{X}^{2} & 0.305 & 4.186 & 9.074 & 1.007 & 7.879 & 4.754 & 6.949 & 7.384 & 0.017 \\ \text { p-value } & 0.581 & \mathbf{0 . 0 4 1} & \mathbf{0 . 0 0 3} & 0.316 & \mathbf{0 . 0 0 5} & \mathbf{0 . 0 2 9} & \mathbf{0 . 0 0 8} & \mathbf{0 . 0 0 7} & 0.898\end{array}$

\section{Vascular Invasion}

$\begin{array}{cccccccccc}\text { Positive } & 18 & 105 & 22 & 15 & 67 & 63 & 54 & 55 & 36 \\ \text { Negative } & 7 & 54 & 10 & 14 & 27 & 30 & 25 & 30 & 16 \\ \mathrm{X}^{2} & 0.304 & 0.020 & 0.118 & 3.603 & 1.297 & 0.028 & 0.085 & 0.373 & 0.137 \\ \text { p-value } & 0.581 & 0.887 & 0.731 & 0.058 & 0.255 & 0.868 & 0.771 & 0.541 & 0.711\end{array}$

ER Status

$\begin{array}{cccccccccc}\text { Positive } & 13 & 110 & 24 & 23 & 63 & 58 & 63 & 50 & 34 \\ \text { Negative } & 12 & 51 & 8 & 5 & 31 & 36 & 17 & 35 & 17 \\ \mathrm{X}^{2} & 3.062 & 0.223 & 0.978 & 1.747 & 0.069 & 1.397 & 7.571 & 4.700 & 0.343 \\ \text { p-value } & 0.080 & 0.637 & 0.616 & 0.186 & 0.793 & 0.237 & 0.006 & 0.030 & 0.558\end{array}$

PR Status

$\begin{array}{cccccccccc}\text { Positive } & 113 & 92 & 26 & 20 & 58 & 49 & 56 & 41 & 35 \\ \text { Negative } & 12 & 69 & 6 & 8 & 37 & 46 & 24 & 44 & 17 \\ \mathrm{X}^{2} & 0.771 & 2.233 & 7.001 & 1.577 & 0.541 & 3.088 & 4.472 & 9.302 & 1.205 \\ \text { p-value } & 0.380 & 0.135 & \mathbf{0 . 0 0 8} & 0.209 & 0.462 & 0.079 & \mathbf{0 . 0 3 4} & \mathbf{0 . 0 0 2} & 0.272\end{array}$

\section{Her2/neu Status}

$\begin{array}{cccccccccc}\text { Positive } & 5 & 48 & 16 & 8 & 23 & 38 & 20 & 30 & 12 \\ \text { Negative } & 18 & 107 & 14 & 18 & 69 & 52 & 55 & 56 & 33 \\ \mathrm{X}^{2} & 0.077 & 1.335 & 6.427 & 0.077 & 4.971 & 5.860 & 0.660 & 1.608 & 0.322 \\ \text { p-value } & 0.781 & 0.248 & \mathbf{0 . 0 1 1} & 0.781 & \mathbf{0 . 0 2 6} & \mathbf{0 . 0 1 5} & 0.417 & 0.205 & 0.570\end{array}$




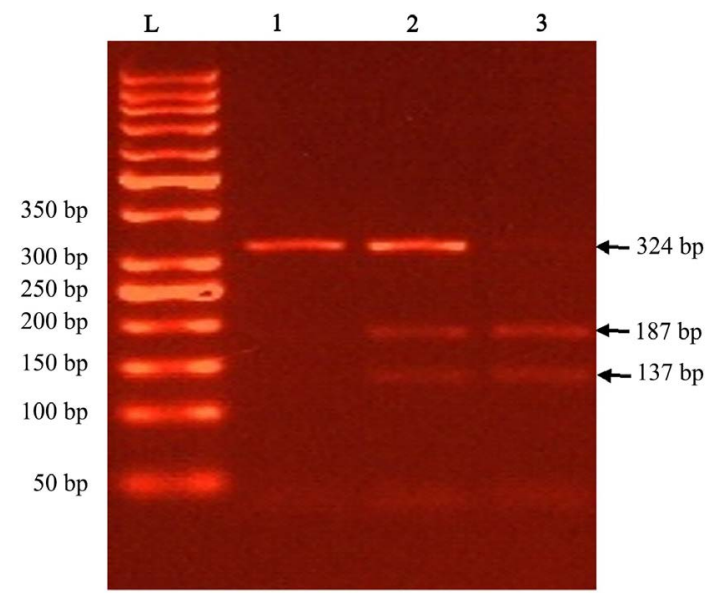

(1a)

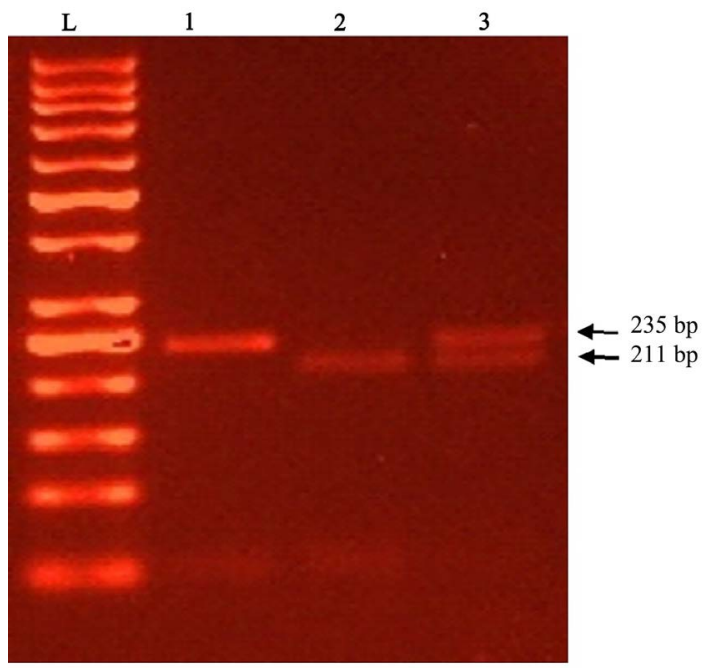

(1b)

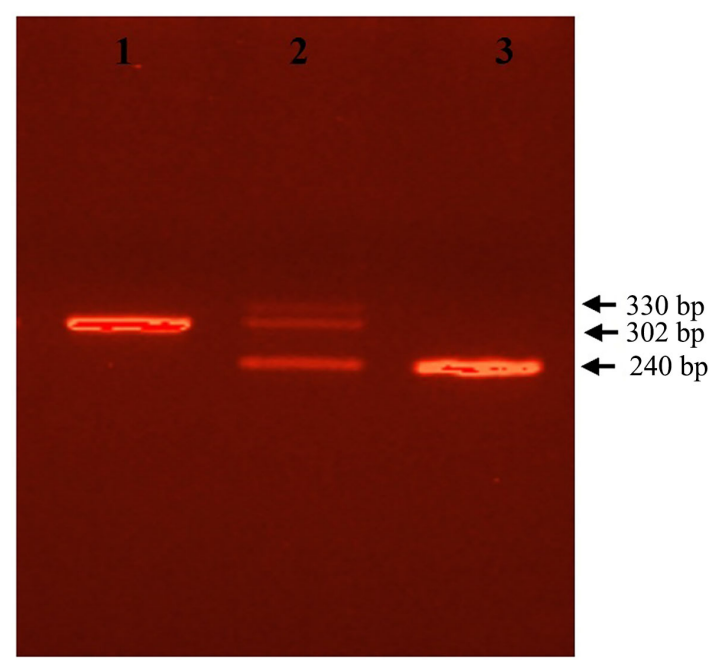

(1c)

Figure 1. Photographs of DNA gel electrophoresis for the detection of hTERT polymorphisms. 1a: rs2736098. Lane 1, AA; Lane 2, AG; lane 3, GG. 1b: rs2735940. Lane 1, TT; lane 2, CC, lane 3, TC. 1c: MNS16A. Lane 1 LL; lane 2 LS; lane 3 SS. L: 50 bp DNA ladder. 


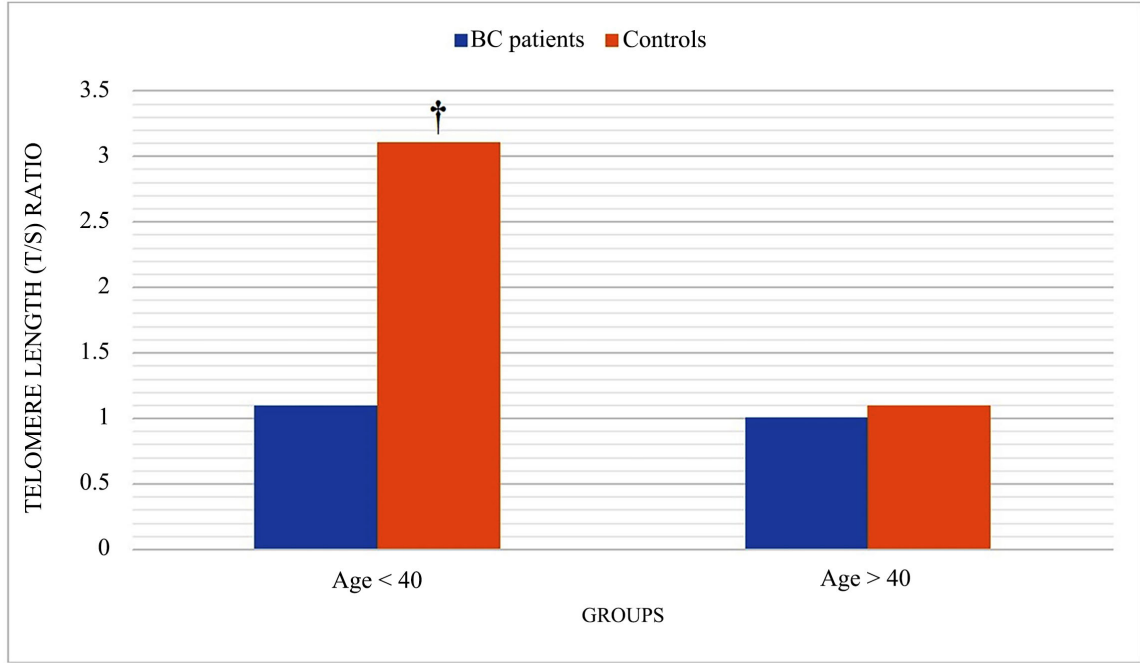

Figure 2. Statistical comparison between telomere in BC patients and control groups according to their age group $(\mathrm{p}<0.05)$.

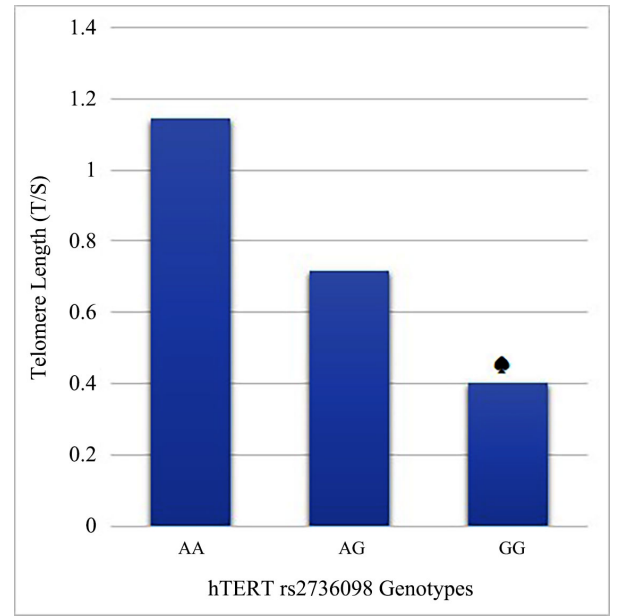

(3a)

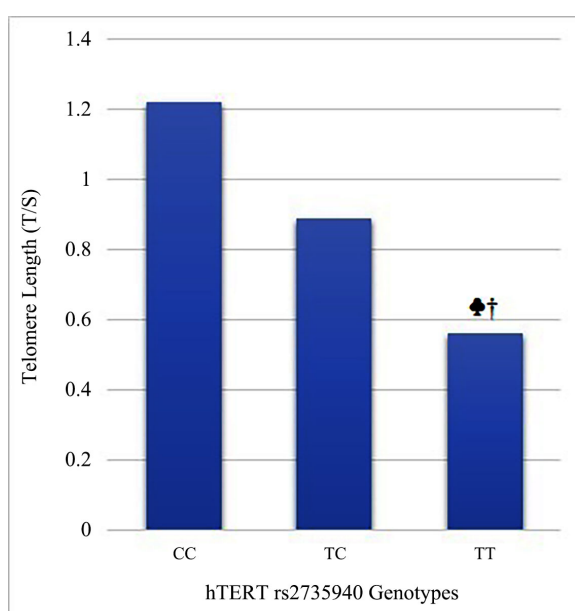

(3b)

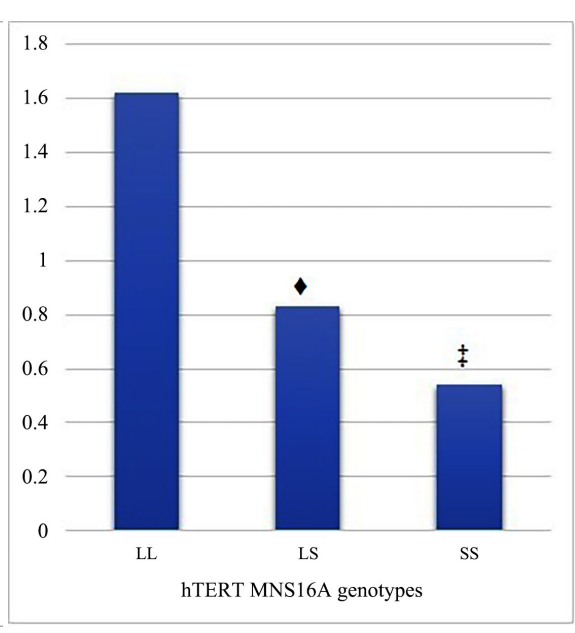

(3c)

Figure 3. Mean telomere length of BC patients stratified according to (3a) rs2736098, (3b) rs2735940 and (3c) MNS16A genotypes respectively. 
One of the most commonly studied SNPs in the TERT gene is the rs2736098G > A polymorphism, it is associated with the risk of many types of cancer [22]. Although this SNP results in silent or synonymous mutation, thus the encoded amino acid remains unchanged (Asn305Asn), it may affect both telomerase activity and TL because of its location within the gene regulatory elements resulting in alteration of transcription factor binding [23].

The results of the present work are supported by many previous studies, Oztas et al. [24], reported that rs2736098 GG genotype is associated with increased risk of $\mathrm{BC}$ among Turkish women $(\mathrm{OR}=1.88)$. Furthermore, $\mathrm{G}$ allele of hTERT rs2736098G $>$ A is reported to be associated with BC risk in Iranian population $(\mathrm{OR}=1.38)$. Hashemi et al. [25] reported that the hTERTrs2736098 G > A variant is associated with BC risk. Their results showed that GA as well as GG and GA + GG increased the risk of BC compared with the AA genotype. The rs2736098 G allele increased the risk of $\mathrm{BC}$ compared with the A allele. A meta-analysis released in 2018 indicated the association between BC susceptibility and rs2736098 variant, where A allele had a protective role against BC in allelic, homozygous, and recessive models [26]. Nevertheless, the association of hTERT rs2736098 variant with $\mathrm{BC}$ risk is inconclusive in some populations. In the Polish population, Savage et al. [27] genotyped different SNPs including rs2736098G > A in the hTERT genomic region, and no significant association with $\mathrm{BC}$ risk was found. Although, his results suggested that $h T E R T$ variants may be associated with the risk in women having a positive family history of $\mathrm{BC}$. On the other hand, in women of African descent, no association was reported [28].

The association between $h T E R T$ rs2735940C $>\mathrm{T}$ polymorphism and cancer susceptibility is contentious. Pande et al. and Walsh et al. reported that either T allele or TT genotype of $h T E R T$ rs $2735940 \mathrm{C}>\mathrm{T}$ polymorphism may be significantly associated with the risk of developing lung cancer in ethnic Koreans, non-Hispanic white population and subjects of African-American ethnicity [29] [30]. In addition, TT genotype was linked with the risk of childhood acute lymphoblastic leukemia in Chinese population [31]. Moreover, Bayram et al. [32] indicated that carriers of TT genotype and/or T allele of $h T E R T$ rs2735940C > T polymorphism are at higher risk of developing gastric cancer in codominant, dominant and log-additive inheritance models. In accordance with the aforementioned data, a meta-analysis involved 19,385 cancer patients and 17,558 healthy subjects indicated that cancer risk significantly increased for $\mathrm{T}$ allele and/or TT genotype of hTERT rs2735940 polymorphism [33]. On the other hand, few studies reported different results. In Caucasian population, hTERT rs2735940C > T polymorphism has no role in colorectal cancer etiology [34]. Iizuka et al. have reported the T allele of $h T E R T$ rs2735940C > T polymorphism may be associated with a decreased risk of epithelial cancer, particularly prostate, lung and prostate cancer [35].

The MNS16A minisatellite region polymorphism in our study didn't show any correlation with neither the risk of developing BC. However, the long allele of 
MNS16A was found to be significantly associated with negative family history and $\mathrm{ER}+/ \mathrm{PR}+$ receptor pattern. Although MNS16A found to be linked with the hTERT activity in many types of cancers, a meta-analysis suggests that MNS16A is associated with the risk of developing gliomas, not other types of cancer including lung, colorectal, nasopharyngeal and breast cancer in Asian and Caucasian population [36]. This variation may be attributed to the differences in microenvironment of tumors of different sites. This may lead to different consequences for the same polymorphism. Collectively, the results of our chosen polymorphisms are comparable to those reported by Hashemi et al. in Iranian population. However, the MNS16A short allele not genotype was significantly associated with cancer risk [25].

Quantitative measurement of leukocyte TL of cancer patients with age less than 40 years showed a significant reduction in TL compared with controls with matched age, however, the TL in both patients and controls with age older than 40 years did not show a significant difference. There was a significant association between $h T E R T$ polymorphisms and telomere length. Telomere plays an essential part in protecting chromosomes and their progressive shortening in somatic cells induces chromosomal instability [37] [38]. Telomere shortening is associated with diverse age-related diseases [39], yet there are inconsistent reports on the relationship between telomere length and cancer incident. Liu et al. have reported that short leukocyte TL contributes to increased susceptibility of gastric cardia adenocarcinoma and, along with lifestyle risk factors, can be considered as a promising prognostic marker [40]. Moreover, the risk of developing lung cancer risks was related to short telomeres lengths in patients with breathing problems, with age, sex, and smoking adjustment [41]. In 2018, Pavanello et al. proposed that telomeres length was shorter in BC patients than age-adjusted controls however their study failed to link it with the risk of hereditary BC [42]. Excessive telomeres shortening drive too many cells into senescence. Senescent cells acquire a senescence-associated secretory phenotype which has deleterious effects on the tissue microenvironment and promotes tumor progression through proinflammatory signaling [43]. Still, other studies showed inconsistent results. Julin et al. findings suggested an association between the risk of overall prostate cancer, including more aggressive disease, with longer leukocyte TL in men with a positive family history of prostate cancer [44]. Similarly, there is an association between longer leukocyte TL and colorectal carcinoma, but not for its premalignant precursors [45]. In light of the results of these studies, further investigations were required to evaluate the possibility of using TL as a biomarker to evaluate the cancer risk.

From the results of the current study, we can conclude that $h T E R T$ rs2736098 and rs27365940, not MNS16A may be associated with increased risk of developing BC in Egyptian females. To our knowledge, this is the first study to investigate these polymorphisms in Egyptian population and their role in breast cancer risk. Also, we can conclude that BC patients younger than 40 years old have 
shorter leukocyte TL when compared to age-matched controls. Thus, telomere length can be a promising screening marker of breast cancer especially in young population.

\section{Conflicts of Interest}

The authors declare no conflicts of interest regarding the publication of this paper.

\section{References}

[1] Bray, F., Ferlay, J., Soerjomataram, I., Siegel, R.L., Torre, L.A. and Jemal, A. (2018) Global Cancer Statistics 2018: GLOBOCAN Estimates of Incidence and Mortality Worldwide for 36 Cancers in 185 Countries. CA: A Cancer Journal for Clinicians, 68, 394-424. https://doi.org/10.3322/caac.21492

[2] Bray, F., McCarron, P. and Parkin, D.M. (2004) The Changing Global Patterns of Female Breast Cancer Incidence and Mortality. Breast Cancer Research, 6, 229-239. https://doi.org/10.1186/bcr932

[3] Abdulkareem, I.H. (2013) Aetio-Pathogenesis of Breast Cancer. Nigerian Medical Journal, 54, 371-375. https://doi.org/10.4103/0300-1652.126284

[4] Lu, W., Zhang, Y., Liu, D., Songyang, Z. and Wan, M. (2013) Telomeres-Structure, Function, and Regulation. Experimental Cell Research, 319, 133-141. https://doi.org/10.1016/j.yexcr.2012.09.005

[5] Meiliana, A., Dewi, N.M. and Wijaya, A. (2017) Telomere in Aging and Age-Related Diseases. The Indonesian Biomedical Journal, 9, 113-128. https://doi.org/10.18585/inabj.v9i3.361

[6] Montpetit, A.J., Alhareeri, A.A., Montpetit, M., Starkweather, A.B., Elmore, L.W., Filler, K., et al. (2015) Telomere Length: A Review of Methods for Measurement. Nursing Research, 63, 289-299. https://doi.org/10.1097/NNR.0000000000000037

[7] Artandi, S.E. and DePinho, R.A. (2010) Telomeres and Telomerase in Cancer. Carcinogenesis, 31, 9-18. https://doi.org/10.1093/carcin/bgp268

[8] Oubaha, M., Miloudi, K., Dejda, A., Guber, V., Mawambo, G., Germain, M.A., et al. (2016) Senescence-Associated Secretory Phenotype Contributes to Pathological Angiogenesis in Retinopathy. Science Translational Medicine, 8, 362ra144. https://doi.org/10.1126/scitranslmed.aaf9440

[9] Hiyama, E. and Hiyama, K. (2007) Telomere and Telomerase in Stem Cells. British Journal of Cancer, 96, 1020-1024. https://doi.org/10.1038/sj.bjc.6603671

[10] Akincilar, S.C., Unal, B. and Tergaonkar, V. (2016) Reactivation of Telomerase in Cancer. Cellular and Molecular Life Sciences, 73, 1659-1670. https://doi.org/10.1007/s00018-016-2146-9

[11] Horn, S., Figl, A., Rachakonda, P.S., Fischer, C., Sucker, A., Gast, A., et al. (2013) TERT Promoter Mutations in Familial and Sporadic Melanoma. Science, 339, 959-961. https://doi.org/10.1126/science.1230062

[12] Li, C., Yin, Z., Wu, W., Li, X. and Zhou, B. (2013) Genetic Variants in TERT-CLPTM1L Genetic Region Associated with Several Types of Cancer: A Meta-Analysis. Gene, 526, 390-399. https://doi.org/10.1016/j.gene.2013.05.003

[13] Long, J., Zhang, B., Signorello, L.B., Cai, Q., Deming-Halverson, S., Shrubsole, M.J., et al. (2013) Evaluating Genome-Wide Association Study-Identified Breast Cancer Risk Variants in African-American Women. PLOS ONE, 8, e58350. 
https://doi.org/10.1371/journal.pone.0058350

[14] Pellatt, A.J., Wolff, R.K., Torres-Mejia, G., John, E.M., Herrick, J.S., Lundgreen, A., et al. (2013) Telomere Length, Telomere-Related Genes, and Breast Cancer Risk: The Breast Cancer Health Disparities Study. Genes, Chromosomes and Cancer, 52, 595-609. https://doi.org/10.1002/gcc.22056

[15] Purrington, K.S., Slager, S., Eccles, D., Yannoukakos, D., Fasching, P.A., Miron, P., et al. (2014) Genome-Wide Association Study Identifies 25 Known Breast Cancer Susceptibility Loci as Risk Factors for Triple-Negative Breast Cancer. Carcinogenesis, 35, 1012-1019. https://doi.org/10.1093/carcin/bgt404

[16] Hofer, P., Baierl, A., Bernhart, K., Leeb, G., Mach, K., Micksche, M., et al. (2012) Association of Genetic Variants of Human Telomerase with Colorectal Polyps and Colorectal Cancer Risk. Molecular Carcinogenesis, 51, E176-E182.

https://doi.org/10.1002/mc.21911

[17] Jin, G., Yoo, S.S., Cho, S., Jeon, H.S., Lee, W.K., Kang, H.G., et al. (2011) Dual Roles of a Variable Number of Tandem Repeat Polymorphism in the TERT Gene in Lung Cancer. Cancer Science, 102, 144-149. https://doi.org/10.1111/j.1349-7006.2010.01782.x

[18] Wang, L., Soria, J.C., Chang, Y.S., Lee, H.Y., Wei, Q. and Mao, L. (2003) Association of a Functional Tandem Repeats in the Downstream of Human Telomerase Gene and Lung Cancer. Oncogene, 22, 7123-7129. https://doi.org/10.1038/sj.onc.1206852

[19] Gil, M.E. and Coetzer, T.L. (2004) Real-Time Quantitative PCR of Telomere Length. Molecular Biotechnology, 27, 169-172. https://doi.org/10.1385/MB:27:2:169

[20] López de Abechuco, E., Soto, M., Pardo, M.A., Haussmann, M. and Díez, G. (2013) Suitability of Real-Time Quantitative PCR to Estimate the Relative Telomere Length in European Hake (Merluccius merluccius Linnaeus, 1758). Revista de Investigación Marina, 20, 29-36.

[21] Leem, S.H., Londoño-Vallejo, J.A., Kim, J.H., Bui, H., Tubacher, E., Solomon, G., et al. (2002) The Human Telomerase Gene: Complete Genomic Sequence and Analysis of Tandem Repeat Polymorphisms in Intronic Regions. Oncogene, 21, 769-777. https://doi.org/10.1038/sj.onc.1205122

[22] Li, T., Xian, Y., Tian, T., Zhuang, X. and Chu, M. (2016) New Evidence of TERT rs2736098 Polymorphism and Cancer Risk: An Updated Meta-Analysis. Journal of B.U.ON.: Official Journal of the Balkan Union of Oncology, 21, 491-497.

[23] Wang, J., Liu, Q., Yuan, S., Xie, W., Liu, Y., Xiang, Y., et al. (2017) Genetic Predisposition to Lung Cancer: Comprehensive Literature Integration, Meta-Analysis, and Multiple Evidence Assessment of Candidate-Gene Association Studies. Scientific Reports, 7, Article No. 8371. https://doi.org/10.1038/s41598-017-07737-0

[24] Oztas, E., Kara, H., Kara, Z.P., Aydogan, M.U., Uras, C. and Ozhan, G. (2016) Association Between Human Telomerase Reverse Transcriptase Gene Variations and Risk of Developing Breast Cancer. Genetic Testing and Molecular Biomarkers, 20, 459-464. https://doi.org/10.1089/gtmb.2015.0339

[25] Hashemi, M., Amininia, S., Ebrahimi, M., Hashemi, S.M., Taheri, M. and Ghavami, S. (2014) Association between hTERT Polymorphisms and the Risk of Breast Cancer in a Sample of Southeast Iranian Population. BMC Research Notes, 7, 895. https://doi.org/10.1186/1756-0500-7-895

[26] Zhou, M., Jiang, B., Xiong, M. and Zhu, X. (2018) Association between TERT rs2736098 Polymorphisms and Cancer Risk-A Meta-Analysis Publication Search and Inclusion Criteria. Frontiers in Physiology, 9, 377. 
https://doi.org/10.3389/fphys.2018.00377

[27] Savage, S.A., Chanock, S.J., Lissowska, J., Brinton, L.A., Richesson, D. and Peplonska, B. (2007) Genetic Variation in Five Genes Important in Telomere Biology and Risk for Breast Cancer. British Journal of Cancer, 97, 832-836. https://doi.org/10.1038/sj.bjc.6603934

[28] Zheng, Y., Ogundiran, T.O., Adebamowo, C., Katherine, L., Domchek, S.M., Rebbeck, T.R., et al. (012) Lack of Association Between Common Single Nucleotide Polymorphisms in the TERT-CLPTM1L Locus and Breast Cancer in Women of African Ancestry. Breast Cancer Research and Treatment, 132, 341-345. https://doi.org/10.1007/s10549-011-1890-7

[29] Pande, M., Spitz, M.R., Wu, X., Gorlov, I.P., Chen, W.V. and Amos, C.I. (2011) Novel Genetic Variants in the Chromosome 5p15.33 Region Associate with Lung Cancer Risk. Carcinogenesis, 32, 1493-1499. https://doi.org/10.1093/carcin/bgr136

[30] Walsh, K.M., Gorlov, I.P., Hansen, H.M., Wu, X., Spitz, M.R., Zhang, H., et al. (2013) Fine-Mapping of the 5p15.33, 6p22.1-p21.31, and 15q25.1 Regions Identifies Functional and Histology-Specific Lung Cancer Susceptibility Loci in African-Americans. Cancer Epidemiology, Biomarkers \& Prevention, 22, 251-260. https://doi.org/10.1158/1055-9965.EPI-12-1007-T

[31] Sheng, X., Tong, N., Tao, G., Luo, D., Wang, M., Fang, Y., et al. (2013) TERT Polymorphisms Modify the Risk of Acute Lymphoblastic Leukemia in Chinese Children. Carcinogenesis, 34, 228-235. https://doi.org/10.1093/carcin/bgs325

[32] Bayram, S., Ülger, Y., Sümbül, A.T., Kaya, B.Y., Genç, A., Rencüzoğullari, E., et al. (2016) Polymorphisms in Human Telomerase Reverse Transcriptase (hTERT) Gene and Susceptibility to Gastric Cancer in a Turkish Population: Hospital-Based Case-Control Study. Gene, 585, 84-92. https://doi.org/10.1016/j.gene.2016.03.030

[33] Yang, H., Li, J., Tang, R., Liu, Y., Shao, Y., Huang, Q., et al. (2015) Telomere Reverse Transcriptase (TERT) rs2735940 Increases Cancer Risk. Medical Science Monitor, 21, 612-616. https://doi.org/10.12659/MSM.893087

[34] Hofer, P., Baierl, A., Feik, E., Fuhrlinger, G., Leeb, G., Mach, K., et al. (2011) MNS16A Tandem Repeats Minisatellite of Human Telomerase Gene: A Risk Factor for Colorectal Cancer. Carcinogenesis, 32, 866-871. https://doi.org/10.1093/carcin/bgr053

[35] Iizuka, T., Sawabe, M., Takubo, K., Liu, M., Homma, Y. and Suzuki, M. (2013) hTERT Promoter Polymorphism, $-1327 \mathrm{C}>\mathrm{T}$, Is Associated with the Risk of Epithelial Cancer. SpringerPlus, 2, 249. https://doi.org/10.1186/2193-1801-2-249

[36] Chen, P., Zou, P., Yan, Q., Xu, H., Zhao, P. and Gu, A. (2013) The TERT MNS16A Polymorphism Contributes to Cancer Susceptibility: Meta-Analysis of the Current Studies. Gene, 519, 266-270. https://doi.org/10.1016/j.gene.2013.02.018

[37] Xu, Y. (2011) Chemistry in Human Telomere Biology: Structure, Function and Targeting of Telomere DNA/RNA. Chemical Society Reviews, 40, 2719-2740. https://doi.org/10.1039/c0cs00134a

[38] Schoepp, N.G., Khorosheva, E.M., Schlappi, T.S., Curtis, M.S., Humphries, R.M., Angeles, L., et al. (2016) Telomere Structure and Maintenance Gene Variants and Risk of Five Cancer Types. International Journal of Cancer, 139, 2655-2670. https://doi.org/10.1002/ijc.30288

[39] Mikhelson, V.M. and Spivak, I.M. (2016) Markers of Cellular Senescence. Telomere Shortening as a Marker of Cellular Senescence. Aging (Albany NY), 8, 3-11. https://doi.org/10.18632/aging.100871

[40] Liu, Y., Lei, T., Zhang, N., Zheng, Y., Kou, P., Shang, S., et al. (2018) Leukocyte Te- 
lomere Length and Risk of Gastric Cardia Adenocarcinoma. Scientific Reports, 8, 14584. https://doi.org/10.1038/s41598-018-32954-6

[41] Karimi, B., Yunesian, M., Nabizadeh, R., Mehdipour, P. and Aghaie, A. (2017) Is Leukocyte Telomere Length Related with Lung Cancer Risk? A Meta-Analysis. Iranian Biomedical Journal, 21, 142-153. https://doi.org/10.18869/acadpub.ibj.21.3.142

[42] Pavanello, S., Varesco, L., Gismondi, V., Bruzzi, P. and Bolognesi, C. (2018) Leucocytes Telomere Length and Breast Cancer Risk/Susceptibility: A Case-Control Study. PLoS ONE, 13, e0197522. https://doi.org/10.1371/journal.pone.0197522

[43] Cahu, J., Bustany, S. and Sola, B. (2012) Senescence-Associated Secretory Phenotype Favors the Emergence of Cancer Stem-Like Cells. Cell Death \& Disease, 3, e446-e448. https://doi.org/10.1038/cddis.2012.183

[44] Julin, B., Shui, I., Heaphy, C.M., Joshu, C.E., Meeker, A.K., Giovannucci, E., et al. (2015) Circulating Leukocyte Telomere Length and Risk of Overall and Aggressive Prostate Cancer. British Journal of Cancer, 112, 769-776. https://doi.org/10.1038/bjc.2014.640

[45] Zöchmeister, C., Brezina, S., Hofer, P., Baierl, A., Bergmann, M.M., Bachleitner-Hofmann, T., et al. (2018) Leukocyte Telomere Length throughout the Continuum of Colorectal Carcinogenesis. Oncotarget, 9, 13582-13592.

https://doi.org/10.18632/oncotarget.24431 